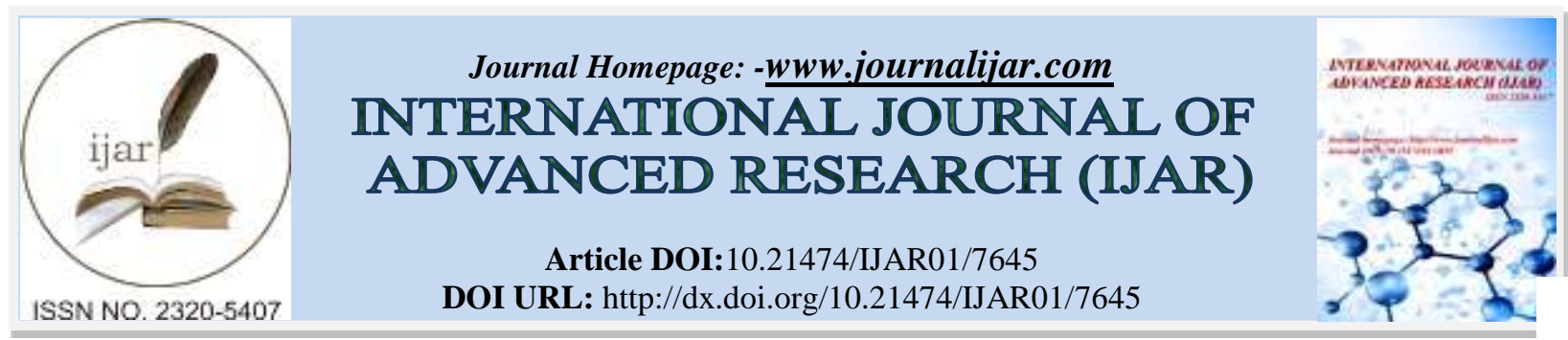

RESEARCH ARTICLE

\title{
APPRAISAL OF PRINCIPALS' RESOURCE MANAGEMENT PRACTICES FOR QUALITY ASSURANCE IN SECONDARY SCHOOLS IN ANAMBRA STATE, NIGERIA.
}

Ugwu Ifeanyichukwu and Eboatu V.N. PHD.

Department of Educational Management and Policy, Nnamdi Azikiwe University, Awka.

\section{Manuscript Info}

Manuscript History

Received: 02 July 2018

Final Accepted: 04 August 2018

Published: September 2018

\section{Abstract}

The prevalence of several indicators of poor-quality assurance practices in secondary schools in Anambra State of Nigeria, such as examination malpractice, inadequate funding, poorly motivated staff and students among others seem to suggest that principals are not operating optimally in terms of resource management practices as prescribed by the government. This prompted the study to assess principals' management practices for quality assurance in secondary schools in Anambra State. Two research questions guided the study and two hypotheses were tested. Descriptive survey research design was adopted for the study. The population of the study comprised all the 257 public secondary school principals in Anambra State. No sampling was done due to the relatively small size of the population of the study. A 21-item questionnaire titled 'Assessment of Principals' Resource Management Practices for Quality Assurance Questionnaire (APRMPQAQ)" was the instrument for data collection. The instrument was subjected to face validation by three experts from Faculty of Education, Nnamdi Azikiwe University. Cronbach-alpha method was used to ascertain the reliability of the instrument. The overall coefficient of 0.84 was obtained. Mean was used to answer the research questions, while Z-test was used to test the null hypotheses at 0.05 level of significance. The findings of the study, among others revealed that principals' human and material resources management for quality assurance in secondary schools in Anambra State was low. It also revealed that there was no significant difference in the mean ratings of male and female principals on the extent of their human and material resources management practices for quality assurance in secondary schools in Anambra State. Based on the findings it was recommended among others that principals should involve the teachers in decision making to improve their participation in achieving school goals. More so, seminars and workshops should be organized for teachers and principals to enhance their managerial practices.

Copy Right, IJAR, 2018, All rights reserved.

\section{Introduction: -}

In Nigeria, public discussions and debates on education frequently focus on the need for consistent improvement on quality and standards. The reason is not far- fetched; Nations of the world are believed to be interested in improving 
their wealth, the living conditions of her people, quality of goods and services enjoyed by the citizenry. One best way of achieving this is by the ensuring that education system is regularly improved upon and the quality is maintained. The principal as the school manager is at the vanguard of ensuring that both human and material resource made available for education are effectively and efficiently utilized and managed in such a way as to bring about consistent improvement in quality of teaching and learning (Abudulraman,2014).

Human resource management practice is concerned with much more than simply filling vacant positions, housekeeping and record-keeping. According to Quartey and Bekoe (2015), human resource management practice is regarded as a strategic approach to acquiring, developing, managing, motivating and gaining the commitment of the people working in an organization. In school organization, the teachers and non-teaching staff constitute the human resource and it is incumbent on the principal to effectively manage them. Meanwhile, human resources maynot sufficiently meet the school objectives without the material resources. Therefore, principals are also expected to demonstrate good management practices in handling not only the physical structures such as mechanical, plumbing, electrical power, telecommunications, security and fire suppression systems but also give attention to furnishings, materials and supplies, equipment and information technology as well as various aspects of building grounds namely athletic fields, playgrounds, areasfor outdoor learning and vehicular access,parking lots and every other teaching aides.

Some pundits are of the position that male principals are better school administrators than their female counterparts. But another set of pundits lend themselves to the contrary. Matheri (2015) for instance, submitted that there is no significant relationship between the principals' gender and their effectiveness in management of personnel, students and finance of their schools. Quality assurance is enhanced through effective human and material resource utilization by the principals, their gender notwithstanding.

Anambra State has been rated very high in West African Senior Secondary Certificate Examination (WASSCE) and National Examination Council(NECO)in recent times but there are still several indicators that seem to suggest principals' poor handlingof both human and material aspects in secondary schoolswhich if not properly handled, have the potency of compromising the quality and standard of secondary education in the state.Ezeaku andOhamobi(2014) observed that one of the common characteristics of some schools in Anambra State is that human and material resources apart from being inadequate are poorly managed. Similarly, Ikediugwu and Chukwumah (2015) noted that the challenges facing secondary schools in Anambra State have been those of poor infrastructure, inadequate staffing, poorly motivated students and poor-quality assurance practices owing to various training limitations (e.g. lack of facilities, equipment and essential reading materials, among others.) More so, Maduemezie (2015) asserted that Anambra State like every other state in Nigeria has had her fair share of examination malpractice. Maduemeziefurther stressed that schools that engage in this act, lose the essence of producing students who will become productive members of their society. It is against this background that it becomes imperative to empirically appraise the principals' resource management practices for quality assurance in secondary schools in Anambra State.

\section{Statement of the Problem: -}

The delivery of high-quality secondary education is very vital for the development of students' potentials and necessary skills to develop Anambra State. Principalsby virtue of their position as the chief executives of secondary schools are responsible for directing, stimulating and controlling both human and material resources to enhance the delivery of improved secondary education. It appears that secondary school principals in Anambra State are not operating optimally in terms of resource management; the persistence of examination malpractice, decayed infrastructure, poor attitude to work among others as observed by the researcher in some secondary schools in Anambra State lends credence to that fact.

Consequently, students are not likely to acquire the needed skills, knowledge and competencies to develop their potentials that would bring about positive development in Anambra State.

\section{Purpose of the Study: -}

The main purpose of this study was to appraise the principals' resource management practices for quality assurance in secondary schools in Anambra State. 


\section{Specifically, the study appraised theprincipals':}

1. Human resource management practices for quality assurance in secondary schoolsin Anambra State.

2. Material resource management practices for secondary schools' improvement in Anambra State.

\section{Research Questions: -}

The following research questions guided the study:

1. What is the extent of principals'human resource management practices forquality assurance in secondary schools in Anambra State?

2. What is the extent of principals' material resource management practices for quality assurance in secondary schools in Anambra State?

\section{Hypotheses: -}

The following null hypotheses were tested at 0.05 level of significance:

1. There is no significant difference in the mean ratings of male and female principals on the extent of theirhuman resource management practices for quality assurance in secondary schools in Anambra State.

2. There is no significant difference in the mean ratings of male and female principals on the extent of theirmaterial resource management practices for quality assurance in secondary schools in Anambra State.

\section{Method: -}

The study adopted the descriptive survey research design. According to Nworgu (2015), descriptive research design aims at collecting data on, describing and assessing in a systematic manner the characteristics, features or facts about a given population. The design was found appropriate for the study because principals' management practices are existing characteristics, features and factsin secondary schools in Anambra State. Therefore, the researcher collected data from principals on the extent of their resource management practices for quality assurance in secondary schools in Anambra State.

The study was conducted in Anambra State.The State has twenty-one Local Government Area with 257 public secondary schools. The state is one of the five states in south-east geopolitical zone of Nigeria with six education zones namely: Aguata, Awka, Nnewi, Ogidi, Onitsha, and Otuocha. The state shares boundaries with Delta and Rivers in the west, Kogi and Enugu in the north, Abia and Imo in the east. The State Post Primary School Service Commission at Awka centrally controls the senior secondary schools. The inhabitants of Anambra State are mainly traders, civil servants and farmers in the rural areas. Anambra State is notable for great enthusiasm and huge investment in education hence the researcher deemed it apt to undertake this study in the state.

The population of the study is made up of 257 respondents comprising 257 principals of public secondary schools in Anambra State. The population distribution of public secondary school principals by education zone are: Aguata 52, Awka 61, Nnewi 48, Ogidi39, Onitsha 31 and Otuocha 26. The above data were as collected fromPost Primary School Service Commission Awka,2018.

All the 257 principals were used for the study. Hence, no sampling was done because of the small size of the population.

The instrument used to elicit information from the respondents isresearcher designed questionnaire titled “Assessment of Principals' Resource Management Practices for Quality Assurance in Secondary Schools Questionnaire" (APRMPQAQ). The instrument has section A which is for the respondents'gender while section B contains items developed by the researcher in line with theresearch questions and hypotheses.Section B is divided into 2 parts. Part 1contains items on human resource management practices of principalsfor quality assurance in secondary school while part 2 contains items on material resource management practices of principals for quality assurance insecondary school. The items are structured on a four-point scale of "Very High Extent (VHE), High Extent (HE), Low Extent (LE) and Very Low Extent (VLE) weighted 4,3,2 and 1 respectively.

The instrument was subjected to face validation using three experts who are lecturers; two from Educational Management and one from Measurement and Evaluation from the Departments of Educational Management and Policy and Educational Foundations respectively all in the Faculty of Education, Nnamdi Azikiwe University. Copies of the questionnaire were given to the experts alongside the purpose of the study, research questions and hypotheses to guide them. They were requested to check the appropriateness of the items in the instruments in 
achieving the purpose of the study and answering the research questions. They thus reviewed the questionnaire items for clarity and appropriateness and made inputs and corrections. Some items in the original instruments were dropped while entirely new items were developed in line with the validators' instructions.

To establish the reliability of the instrument, twenty-four public secondary schools were sampled using simple random sampling techniquefrom Enugu state which is not part of the population ofthe study. Twenty-four principals of the sampled schools were used. Copies of the questionnaire were administered on them. Cronbach alpha method was used to determine the internal consistency of the items. The reliability coefficients for the five parts of the instrument were $0.83,0.85,0.83,0.84$ and 0.85 respectively, while the overall reliability coefficient of the instrument was 0.84.In line with Fraenkel and Wallen, (2000) who maintained that items will be considered reliable and desirable for consistency level if they yield a reliability coefficient of 0.70 and above, the instrument was considered reliable for the study.

Two hundred and fifty-seven (257) copies of the questionnaire were administered to the respondents by the researcher with the help of six research assistants. The research assistants were post-graduate students of Department of Educational Management and Policy, Faculty of Education, Nnamdi Azikiwe University. They are suitable as they have been exposed to the rudiments of research. To further enhance their performance, they were briefed by the researcher on the nature of the study including the purpose of the study. This was to ensure that they have a good knowledge of the study and this helped them to answer questions and make clarifications that the respondentsdemanded from them in the course of data distribution and collection. Direct approach method of distribution wasemployed, and the exercise lasted for six months. Two hundred and forty-two (242) copies of the questionnaire that were distributed were properly filled and retrieved indicating $94 \%$ return rate.

The research questions were answered using mean statistics and standard deviation, while the hypotheses were tested using t-test. There was need for the opinions of all the principals that participated in this study to be considered, hence, mean statistics was used because by the very nature of the way in which mean is computed, it takes into account, or is based on, each and every participant's score, so that the scores of each participant count. Male and female principals were the groups that participated in this study so, t-test was used because t-test, determines whether the means of two groups are significantly different at a selected probability level. In answering the research questions in this study, mean between: 4.00-3.50, 3.49-2.50, 2.49-1.50, and 1.49-below were taken to indicate: VHE, HE, LE, VLE respectively. In testing the null hypotheses, when t-calculated is less than t-critical at 0.05 level of significance and degree of freedom, the null hypotheses wasnot rejected but when t-calculated is equal to or greater than the t-critical, it was rejected.

\section{Results: -}

\section{Research Question 1: -}

What is the extent of principals'human resource management practices for quality assurance in secondary schools in Anambra State?

Table1: -Mean Ratings and Standard Deviations on Male and Female Principals'Human Resource Management Practices for Quality Assurance in Secondary Schools in Anambra State.

\begin{tabular}{|c|c|c|c|c|c|c|c|c|c|c|}
\hline \multirow[t]{2}{*}{$\mathbf{S} / \mathbf{N}$} & \multirow[t]{2}{*}{ ITEMS } & \multicolumn{3}{|c|}{$\begin{array}{l}\text { MALE PRINCIPALS } \\
\qquad(\mathbf{N}=\mathbf{1 1 3})\end{array}$} & \multicolumn{3}{|c|}{$\begin{array}{c}\text { FEMALE } \\
\text { PRINCIPALS } \\
(\mathbf{N}=129)\end{array}$} & \multicolumn{3}{|c|}{ TOTAL $(\mathrm{N}=242)$} \\
\hline & & Mean & $\mathrm{Sd}$ & Remark & Mean & $\mathrm{Sd}$ & Remark & Mean & $\mathrm{Sd}$ & Remark \\
\hline 1 & $\begin{array}{l}\text { Involving the teachers in } \\
\text { decision making to improve } \\
\text { their participation towards } \\
\text { achieving school goals }\end{array}$ & 2.01 & 1.03 & $\begin{array}{l}\text { Low } \\
\text { Extent }\end{array}$ & 1.99 & 1.04 & $\begin{array}{l}\text { Low } \\
\text { Extent }\end{array}$ & 2.00 & 1.03 & $\begin{array}{l}\text { Low } \\
\text { Extent }\end{array}$ \\
\hline 2 & $\begin{array}{l}\text { Involving the teachers in } \\
\text { setting school goals in } \\
\text { order to help keep teachers } \\
\text { informed about the school } \\
\text { goals from the very }\end{array}$ & 2.06 & 1.03 & $\begin{array}{l}\text { Low } \\
\text { Extent }\end{array}$ & 2.10 & .97 & $\begin{array}{l}\text { Low } \\
\text { Extent }\end{array}$ & 2.09 & .99 & $\begin{array}{l}\text { Low } \\
\text { Extent }\end{array}$ \\
\hline
\end{tabular}




\begin{tabular}{|c|c|c|c|c|c|c|c|c|c|c|}
\hline & beginning & & & & & & & & & \\
\hline 3 & $\begin{array}{l}\text { Carrying the teachers along } \\
\text { in reviewing the school } \\
\text { goals for } \\
\text { improvement }\end{array}$ & 2.22 & 1.06 & $\begin{array}{l}\text { Low } \\
\text { Extent }\end{array}$ & 2.20 & 1.08 & $\begin{array}{l}\text { Low } \\
\text { Extent }\end{array}$ & 2.20 & 1.07 & $\begin{array}{l}\text { Low } \\
\text { Extent }\end{array}$ \\
\hline 4 & $\begin{array}{l}\text { Managing the school } \\
\text { through the establishment } \\
\text { of committees so as to } \\
\text { bring about efficiency in } \\
\text { school administration }\end{array}$ & 2.69 & 1.09 & $\begin{array}{l}\text { High } \\
\text { Extent }\end{array}$ & 2.73 & 1.11 & $\begin{array}{l}\text { High } \\
\text { Extent }\end{array}$ & 2.72 & 1.10 & $\begin{array}{l}\text { High } \\
\text { Extent }\end{array}$ \\
\hline 5 & $\begin{array}{l}\text { Motivating the teachers for } \\
\text { improved performance }\end{array}$ & 2.16 & 1.06 & $\begin{array}{c}\text { Low } \\
\text { Extent }\end{array}$ & 2.16 & 1.08 & $\begin{array}{l}\text { Low } \\
\text { Extent }\end{array}$ & 2.16 & 1.07 & $\begin{array}{l}\text { Low } \\
\text { Extent }\end{array}$ \\
\hline 6 & $\begin{array}{l}\text { Motivating the students for } \\
\text { improved performance }\end{array}$ & 2.26 & 1.07 & $\begin{array}{c}\text { Low } \\
\text { Extent }\end{array}$ & 2.23 & 1.15 & $\begin{array}{l}\text { Low } \\
\text { extent }\end{array}$ & 2.24 & 1.12 & $\begin{array}{l}\text { Low } \\
\text { Extent }\end{array}$ \\
\hline 7 & $\begin{array}{l}\text { Delegating duties to the } \\
\text { staff in order to expose } \\
\text { them to challenges that } \\
\text { come with responsibility }\end{array}$ & 2.84 & 1.08 & $\begin{array}{c}\text { High } \\
\text { Extent }\end{array}$ & 2.56 & 1.14 & $\begin{array}{l}\text { High } \\
\text { extent }\end{array}$ & 2.66 & 1.12 & $\begin{array}{l}\text { High } \\
\text { Extent }\end{array}$ \\
\hline 8 & $\begin{array}{l}\text { Delegating duties to the } \\
\text { students to improve their } \\
\text { commitment to school } \\
\text { business }\end{array}$ & 2.17 & 1.05 & $\begin{array}{l}\text { Low } \\
\text { Extent }\end{array}$ & 2.57 & 1.11 & $\begin{array}{l}\text { High } \\
\text { Extent }\end{array}$ & 2.44 & 1.11 & $\begin{array}{l}\text { Low } \\
\text { Extent }\end{array}$ \\
\hline 9 & $\begin{array}{lr}\text { Conducting } & \text { staff } \\
\text { performance appraisal so as } \\
\text { to encourage better } \\
\text { performance } & \text { and } \\
\text { improvement } & \end{array}$ & 1.90 & 1.01 & $\begin{array}{l}\text { Low } \\
\text { Extent }\end{array}$ & 2.27 & 1.08 & $\begin{array}{l}\text { Low } \\
\text { Extent }\end{array}$ & 2.14 & 1.07 & $\begin{array}{l}\text { Low } \\
\text { Extent }\end{array}$ \\
\hline 10 & $\begin{array}{l}\text { Promote teachers' welfare } \\
\text { to improve their } \\
\text { commitment }\end{array}$ & 2.31 & 1.14 & $\begin{array}{l}\text { Low } \\
\text { Extent }\end{array}$ & 2.34 & 1.07 & $\begin{array}{l}\text { Low } \\
\text { Extent }\end{array}$ & 2.33 & 1.09 & $\begin{array}{l}\text { Low } \\
\text { Extent }\end{array}$ \\
\hline 11 & $\begin{array}{l}\text { Organizing seminars or } \\
\text { workshops for professional } \\
\text { development of teachers }\end{array}$ & 1.83 & .90 & $\begin{array}{l}\text { Low } \\
\text { Extent }\end{array}$ & 2.04 & .99 & $\begin{array}{l}\text { Low } \\
\text { Extent }\end{array}$ & 1.97 & .96 & $\begin{array}{l}\text { Low } \\
\text { Extent }\end{array}$ \\
\hline & Mean of means' & 2.22 & 1.05 & $\begin{array}{c}\text { Low } \\
\text { Extent }\end{array}$ & 2.29 & 1.07 & $\begin{array}{l}\text { Low } \\
\text { Extent }\end{array}$ & 2.27 & 1.07 & $\begin{array}{l}\text { Low } \\
\text { Extent }\end{array}$ \\
\hline
\end{tabular}

Table 1 revealed that item 1,2, 3, 5, 6 and 9-11 fall within the range of 1.50-2.49 indicating that the extent of male and female principals' human resource management was low. Items 4 and 7 fall within the range of 2.50-3.49 indicating high extent of male and female principals' human resource management. While, there was low extent of male principals' human resource management in item 8, there was high extent of female principals' human resource management with the same item. The standard deviations of 1.05 and 1.07 for male and female principals respectively indicate convergence and closer disparity from the mean scores. The mean of means' scores of 2.22 and 2.29 of male and female principals respectively as well as the general mean of means of 2.27 which falls within the range of 1.50-2.49 indicates low extent of principals'human resource management practices for quality assurance in secondary schools in Anambra State.

\section{Research Question 2}

What is the extent of principals'material resource management practices for quality assurance in secondary schools in Anambra State?

Table2: -Mean Ratings and Standard Deviationson Male and Female Principals'Material Resource Management Practices for Quality Assurance in Secondary Schoolsin Anambra State.

\begin{tabular}{|c|c|c|c|c|}
\hline S/N & ITEMS & $\begin{array}{c}\text { MALE PRINCIPALS } \\
(\mathbf{N}=113)\end{array}$ & $\begin{array}{c}\text { FEMALE } \\
\text { PRINCIPALS } \\
(\mathbf{N}=129)\end{array}$ & TOTAL $(\mathbf{N}=242)$ \\
\hline
\end{tabular}




\begin{tabular}{|c|c|c|c|c|c|c|c|c|c|c|}
\hline & & Mean & $\mathrm{Sd}$ & Remark & Mean & $\mathrm{Sd}$ & Remark & Mean & $\mathrm{Sd}$ & Remark \\
\hline 12 & $\begin{array}{lr}\text { Ensuring that school } \\
\text { building are kept clean for } \\
\text { a better learning } \\
\text { environment }\end{array}$ & 2.64 & 1.11 & $\begin{array}{l}\text { High } \\
\text { Extent }\end{array}$ & 2.58 & 1.13 & $\begin{array}{l}\text { High } \\
\text { Extent }\end{array}$ & 2.60 & 1.12 & $\begin{array}{l}\text { High } \\
\text { Extent }\end{array}$ \\
\hline 13 & $\begin{array}{llr}\text { Ensuring } & \text { that } & \text { toilet } \\
\text { facilities are tidy to avoid } \\
\text { exposing } & \text { learners } & \text { to } \\
\text { infections } & & \\
\end{array}$ & 2.54 & 1.03 & $\begin{array}{c}\text { High } \\
\text { Extent }\end{array}$ & 2.57 & 1.06 & $\begin{array}{l}\text { High } \\
\text { Extent }\end{array}$ & 2.55 & 1.06 & $\begin{array}{l}\text { High } \\
\text { Extent }\end{array}$ \\
\hline 14 & $\begin{array}{l}\text { Ensuring that classrooms } \\
\text { are equipped with furniture } \\
\text { so that students can } \\
\text { comfortably sit down and } \\
\text { learn }\end{array}$ & 2.17 & 1.11 & $\begin{array}{c}\text { Low } \\
\text { Extent }\end{array}$ & 2.33 & 1.06 & $\begin{array}{l}\text { Low } \\
\text { Extent }\end{array}$ & 2.27 & 1.08 & $\begin{array}{l}\text { Low } \\
\text { Extent }\end{array}$ \\
\hline 15 & $\begin{array}{l}\text { Ensuring that library is } \\
\text { stocked with needed books } \\
\text { for assignment and research } \\
\text { purposes }\end{array}$ & 2.61 & 1.11 & $\begin{array}{c}\text { High } \\
\text { Extent }\end{array}$ & 2.43 & 1.10 & $\begin{array}{l}\text { Low } \\
\text { Extent }\end{array}$ & 2.49 & 1.10 & $\begin{array}{l}\text { Low } \\
\text { Extent }\end{array}$ \\
\hline 16 & $\begin{array}{l}\text { Ensuring that laboratory is } \\
\text { equipped with chemicals } \\
\text { for experiment }\end{array}$ & 1.82 & .92 & $\begin{array}{c}\text { Low } \\
\text { Extent }\end{array}$ & 2.25 & 1.05 & $\begin{array}{l}\text { Low } \\
\text { Extent }\end{array}$ & 2.10 & 1.02 & $\begin{array}{l}\text { Low } \\
\text { Extent }\end{array}$ \\
\hline 17 & $\begin{array}{l}\text { Ensuring that ICT facilities } \\
\text { are kept in good and } \\
\text { working condition to } \\
\text { encourage ICT knowledge } \\
\text { among teachers and } \\
\text { students }\end{array}$ & 2.27 & 1.07 & $\begin{array}{c}\text { Low } \\
\text { Extent }\end{array}$ & 2.39 & 1.11 & $\begin{array}{l}\text { Low } \\
\text { Extent }\end{array}$ & 2.35 & 1.09 & $\begin{array}{l}\text { Low } \\
\text { Extent }\end{array}$ \\
\hline 18 & $\begin{array}{l}\text { Ensuring sporting facilities } \\
\text { are regularly maintained to } \\
\text { encourage exercise among } \\
\text { teachers and students }\end{array}$ & 2.27 & 1.12 & $\begin{array}{c}\text { Low } \\
\text { Extent }\end{array}$ & 2.15 & 1.09 & $\begin{array}{l}\text { Low } \\
\text { Extent }\end{array}$ & 2.19 & 1.10 & $\begin{array}{l}\text { Low } \\
\text { Extent }\end{array}$ \\
\hline 19 & $\begin{array}{l}\text { Ensuring that procedures } \\
\text { are put in place to in } \\
\text { preparation to cope with } \\
\text { fire and other emergencies }\end{array}$ & 2.28 & 1.09 & $\begin{array}{l}\text { Low } \\
\text { Extent }\end{array}$ & 2.18 & 1.04 & $\begin{array}{l}\text { Low } \\
\text { Extent }\end{array}$ & 2.22 & 1.06 & $\begin{array}{l}\text { Low } \\
\text { Extent }\end{array}$ \\
\hline 20 & $\begin{array}{l}\text { Ensuring that procedures } \\
\text { are put in place to ward-off } \\
\text { vandals from the school }\end{array}$ & 2.33 & 1.06 & $\begin{array}{l}\text { Low } \\
\text { Extent }\end{array}$ & 2.24 & 1.13 & $\begin{array}{l}\text { Low } \\
\text { Extent }\end{array}$ & 2.27 & 1.10 & $\begin{array}{l}\text { Low } \\
\text { Extent }\end{array}$ \\
\hline \multirow[t]{2}{*}{21} & $\begin{array}{l}\text { Judiciously spends the } \\
\text { funds made available to the } \\
\text { school so that the needed } \\
\text { resources for learning are } \\
\text { provided for improved } \\
\text { learning }\end{array}$ & 2.57 & 1.16 & $\begin{array}{l}\text { High } \\
\text { Extent }\end{array}$ & 3.21 & .81 & $\begin{array}{l}\text { High } \\
\text { Extent }\end{array}$ & 2.99 & .99 & $\begin{array}{l}\text { High } \\
\text { Extent }\end{array}$ \\
\hline & Mean of means' & 2.35 & 1.04 & $\begin{array}{c}\text { Low } \\
\text { Extent }\end{array}$ & 2.43 & .99 & $\begin{array}{l}\text { Low } \\
\text { Extent }\end{array}$ & 2.40 & 1.07 & $\begin{array}{l}\text { Low } \\
\text { Extent }\end{array}$ \\
\hline
\end{tabular}

Table 2 revealed that items 12 and 21 with the mean scores within the range of 2.50-3.49 indicating high extent of male and female principals' engagement with the items. Items 13, 14 and 16-21 fall within the range of 1.50-2.49 indicating that the extent of male and female principals' engagement with the items was low. While, there was high extent of male principals' materials resource management with item 15, there was low extent of female principals withthe same item. The standard deviations of 1.04 and .99 for male and female principals respectively indicate similarity the pattern of their response and near-same disparity from the mean scores. The mean of means' scores of 2.35 and 2.43 of male and female principals respectively as well as the general mean of means of 2.40 which falls 
within the range of 1.50-2.49 indicates low extent of principals' material resource management practices for quality assurance in secondary schools in Anambra State.

\section{Testing the Null Hypotheses: -}

$\mathrm{Ho}_{\mathbf{1}}$ : There is no significant difference in the mean ratings of male and female principals on the extent of their human resource management practices for quality assurance in secondary schools in Anambra State.

Table 3: - t-test of Male and Female Principalson the Extent of their Human Resource Management Practices for Quality Assurance in Secondary Schools

\begin{tabular}{lccccccl|}
\hline Groups & $\mathbf{N}$ & $\overline{\mathbf{X}}$ & Sd & t-cal. & t-crit. & Df & Decision \\
\hline Male & 113 & 2.22 & 1.05 & -0.51 & 1.96 & 240 & Not Significant \\
Female & 129 & 2.29 & 1.07 & & & & \\
\hline
\end{tabular}

From Table 3, the t-calculated value of -0.51 is less than $t$-critical value of 1.96 at 0.05 levels of significant and for the degree of freedom of 240. Thus, the null hypothesis is not rejected. Therefore, there is no significant difference in the mean ratings of male and female principals on the extent of their compliance with FME human resource management practices for secondary schools' improvement in Anambra State.

$\mathrm{Ho}_{2}$ : There is no significant difference in the mean ratings of male and female principals on the extent of their material resource management practices for quality assurance in secondary schools in Anambra State.

Table 4: t-test of Male and Female Principalson the Extent of theirMaterial resource Management Practices for Quality Assurance in Secondary Schools

\begin{tabular}{l|ccccccl|}
\hline Groups & $\mathbf{N}$ & $\overline{\mathbf{X}}$ & $\mathbf{S d}$ & t-cal. & t-crit. & Df & Decision \\
\hline Male & 113 & 2.30 & 1.04 & -0.61 & 1.96 & 240 & Not Significant \\
Female & 129 & 2.40 & .99 & & & & \\
\hline
\end{tabular}

From Table 4, the t-calculated value of -0.61 is less than $\mathrm{t}$-critical value of 1.96 at 0.05 levels of significant and for the degree of freedom of 240. Thus, the null hypothesis is not rejected. Therefore, there is no significant difference in the mean ratings of male and female principals on the extent of their compliance with FME material resource management practices for secondary schools' improvement in Anambra State

\section{Discussion of Findings: -}

The result of data analyzed in table 1 revealed that there is low extent of principals' human resource management practices for quality assurance in secondary schools in Anambra State. This shows that principals in Anambra State are yet to fully utilize and effectively manage the human capital in the schools. This finding is in line with the study of Ofojebe and Egboka (2008) which indicated that principals' utilization of strategic supervision and human relations competencies is low. The finding of this study is also in agreement with the study of Asogwa (1990) who reported that of all the functions of management, principals' level of consideration for most of the identified human resource management functions were very low. This implies among others that principals do not involve the teachers in decision making and setting school goals, do not adequately motivate the teachers and students. They neither sufficiently improve the teachers' welfare nor organize seminars or workshops for professional development of the teachers. The null hypothesis one in table 3 revealed that there is no significant difference in the mean ratings of male and female principals on the extent they apply human resource management practices for secondary education improvement in Anambra State. This finding is in agreement withOboegbulem and Kalu (2013) who earlier reported that there was no significant difference in the mean ratings of male and female principals on the influences of gender in planning and implementation of personnel management functions. This implies among others that male and female principals engage in human resource management practices for quality assurance in secondary schools in Anambra State to a low extent.

The result of data analyzed in Table 2 revealed that there is low extent ofprincipals' material resource management practices for quality assurance in secondary schools in Anambra State. This finding is contrary to the finding of Allan Dodd (2006) whose study revealed that principals of the schools studied applied material resource management practices for school effectivenessto a great extent. The difference in the findings of the two studies may 
have been attested to by the time lag and difference in the locations of the areas of the studies. The null hypothesis 2 in table revealed that there is no significant difference in the mean ratings of male and female principals on the extent of theirmaterial resource management practices for quality assurance in secondary schools in Anambra State. This is supported by Matheri (2015) who found out that there was no significant relationship between the principals' gender and effectiveness in the management of school resources. This among other things implies that male and female principals apart from financial prudence engage in material resource management practices for quality assurance in secondary schools in Anambra State to a low extent.

\section{Conclusion: -}

Based on the findings of this study, it was concluded that there is low extent of principals' resource management practices for quality assurance in secondary schools in Anambra State. This implies that there was low extent of principals' human and material resource management practices for quality assurance in secondary schools in Anambra State.

\section{Recommendations: -}

Based on the findings of this study, it was recommended among others that: -

Principals should involve the teachers in decision making to improve their participation in achieving school goals. More so, seminars and workshops should be organized for teachers and principals to enhance their professional development.

Principals should ensure that ICT facilities are kept in good and working condition to encourage ICT knowledge among staff and students and also ensure that laboratories are equipped with chemicals for experiments.

\section{References: -}

1. Abudulraman, M. (2014). Principals' administrative process strategies for the achievement of quality assurance in secondary schools in Kogi State. Unpublished Masters' Thesis. Department of Educational Administration and Planning. University of Nigeria, Nsukka

2. Allan, D. (2006). Investigating the effective use of resources in secondary schools. Journal of Educational Leadership, 5(5), 45-51.

3. Ezeaku, S.N. \&Ohamobi, I.N. (2014). Competiveness in education and legal issues: A step towards quality assurance in secondary education in Anambra State. Journal of Educational Practice, 2(1), 23-31.

4. Ikediugwu, N. P. \&Chukwumah, F. O. (2015). Strategic plan implementation and monitoring in secondary schools in Anambra state. Greener Journal of Educational Research, 5(2), 17-26.

5. Matheri, E.W. (2015). Principals' gender and management effectiveness in secondary schools.Journal of education and practice, 6(14) 23-35

6. Nworgu, B.G. (2015). Educational Research: Basic issues and methodology (3 ${ }^{\text {rd }}$ ed.). Enugu: University Trust Publishers.

7. Oboegbulem, A. I. \& Kalu, A.F. (2013). Budgeting practices of principals of secondary schools in south- east geo-political zone of Nigeria.Journal of Education and Practice, 4(22), 194-204.

8. Quartey, E.F \&Bekoe, R. (2015). Human resource management practices in Senior High $\quad$ Schools in the Awkapim North District in the Eastern Region of Ghana. Koforidua Polytechnic, Ghana. 